\title{
KONTEKSTUALISASI FILOLOGI DALAM TEKS-TEKS ISLAM NUSANTARA
}

\author{
Khabibi Muhammad Luthfi \\ Institut Pesantren Mathali'ul Falah \\ Jl. Pati-Tayu KM.4 Purworejo, Margoyoso, Pati, Jawa Tengah \\ E-mail: habibi.abeb@gmail.com
}

Abstract: This paper aims to explore the concepts, methods and significance of philology Islam Nusantara and contextualization in manuscripts from Indonesia. It departs from the problems that the Islamic manuscripts archipelago that has not been widely studied, whereas in it save the value, thought and culture of the past scholars Nusantara which would clarify the concept of Islam Nusantara itself. With the approach of descriptive data-based literature and discourse analysis found that the concepts, methods and significance of philology Islam Nusantara almost the same as philology in general and the only difference being the object of study, in addition to the contextualization as an approach to the study of Islam in Indonesia, particularly related to Islamic manuscripts archipelago could be advised to use The new philology without leaving classical philology.

Keywords: philology, manuscripts, texts, Islam, Indonesian archipelago.

Abstrak: Tulisan ini bertujuan mengeksplorasi konsep, metode dan signifikansi filologi Islam Nusantara serta kontekstualisasinya dalam pernaskahan Indonesia. Ini berangkat dari persoalan bahwa manuskrip Islam Nusantara yang belum banyak dikaji, padahal di dalamnya menyimpan nilai, pemikiran dan budaya ulama nusantara masa lampau yang tentunya akan menjernihkan mengenai konsep Islam Nusantara itu sendiri. Dengan pendekatan deksriptif berbasis data pustaka dan analisis wacana ditemukan bahwa konsep, metode dan signifikansi filologi Islam Nusantara hampir sama dengan filologi pada umumnya dan yang membedakan hanya objek kajiannya, selain itu kontektualisasinya sebagai pendekatan studi Islam di Indonesia, terutama terkait manuskrip Islam Nusantara bisa disarankan menggunakan filologi baru tanpa meninggalkan filologi klasik.

Kata Kunci: filologi, manuskrip, teks, Islam, Nusantara. 


\section{A. Pendahuluan}

Islam-dalam bahasa Nasr Hamid Abu Zaid-merupakan agama yang dibangun berdasarkan peradaban teks (hậ̄ārah an-nas)-baca: al-Quran (Nasr Hamid Abu Zaid, 2003: 1). Apa pun yang terkait dengan Islam pasti akan merujuk teks. Teks pertama dalam Islam adalah al-Quran dan hadis. Sedangkan teks kedua adalah pemahaman umat muslim terhadap teks pertama. Teks kedua pun akan melahirkan teks ketiga, yaitu teks yang dipahami dari teks kedua dan seterusnya. Sebagai umat Islam yang hidup di 1437 tahun setelah kenabian tentu akan akan mempelajari teks-teks di atas-entah teks yang ke berapa-secara bertahap agar sampai pada pemahaman pada teks yang pertama.

Teks sendiri adalah pemahaman yang bersifat abstrak yang terdapat dalam suatu naskah yang berbentuk konkrit seperti buku atau lembaran kertas. Pada saat ini mungkin tidak ada problem mengenai naskah, karena berbasis mesin cetak. Namun naskah yang memuat teks kedua, ketiga atau seterusnya yang diciptakan ulama Nusantara di masa lampu yang penuh keterbatasan tentu menyisakan persoalan tersendiri atau bisa jadi sulit terbaca umat muslim Indonesia sekarang. Padahal di dalam naskah tersebut memuat ilmu-ilmu dan budaya keislaman Nusantara yang berkembang pada saat itu.

Dalam konteks tersebut pendekatan filologi mamainkan peran dalam mengkaji Islam yang terdapat dalam naskah atau teks kuno, terutama di Nusantara dan juga dianggap sebagai l'ectalage de savoir, pemeran ilmu pengetahuan Islam (Nafron Hasjim, 1985: 1). Artinya, Berkat filologi, umat muslim Nusantara bisa "berdebat" ilmiah dengan umat Islam klasik baik di Nusantara sendiri maupun di Timur Tengah bahkan dunia Islam pada umumnya. Tidak bisa dibayangkan bagaimana jika umat muslim Indonesia tidak tahu tentang Islam masa lampau. Yang ada, mungkin muslim itu menjadi "gila" dan "linglung" karena tidak mengetahui akar identitas keislamannya-sebagaimana beberapa kelompok Islam yang ahistori dengan jargon kembali kepada al-Quran dan sunnah.

Sayang, sejauh ini, di Nusantara menurut Oman Fathurahman (2010: vii) tulisan yang membahas seluk beluk teori dan metode filologi masih sangat kurang, mungkin malahan masih 'jalan di tempat'. Kebanyakan tulisan yang beredar hanya mempublikasikan katalog naskah atau hasil penelitian atas naskah Islam Nusantara. Padahal masih tersimpan ribuan, bahkan jutaan naskah kuno yang belum diteliti baik oleh cendekiawan muslim maupun non-muslim atau para pakar asing. Selain itu, karena ilmu ini terlalu sibuk dengan masa lalu dan "kurang peduli" masa depan, oleh beberapa kalangan cendekia, filologi dianggap sebagai kajian kuno yang kurang relevan di era postmodern. Kesan miring ini pun diamini 
oleh Azyumardi Azra (2012: 2). Baginya, filologi akan kembali hidup manakala ada politic will dari pemerintah.

Berangkat dari arti penting dan problem filologi di atas, tulisan ini akan sedikit mengurai konsep dasar, signifikansi dan metodologi filologi Islam Nusantara. Sebagai sebuah ilmu 'tua' di dalamnya juga terdapat friksi-variasi dari sisi ontologis dan epistemologis, sehingga perlu upaya mendudukan kajian ini. Tepatnya, kontekstualisasi mazhab baru dalam filologi untuk kajian pernaskahan Islam Nusantara akan dikupas.

\section{B. Konsep Filologi Islam Nusantara: Sebuah Pengantar}

Secara etimologi filologi berasal dari bahasa Yunani, philos yang mempunyai makna cinta (love) dan logos yang berarti kata (word), artikulasi (articulation) dan alasan (reason). Dengan begitu, filologi bisa diartikan cinta terhadap kata atau bisa juga senang bertutur, berbicara dengan berargumentasi. It ulah sebab kenapa filolog selalu bermain-main dan suka terhadap kata dan teks. Makna ini pada perkembangannya bergeser menjadi senang belajar (learning), senang ilmu, senang kebudayaan dan senang kasusastraan (Siti Baroroh Baried dkk., 1985: 1).

Menurut R. H. Robins (1992: 7) pengertian filologi terutama di tradisi Inggris-Britania disamakan dengan linguistik komparatif-historis (muqāranahtārīkhiyah). Di Inggris bagian lain dan beberapa negara Eropa dan Amerika menyebutnya dengan filologi komparatif yang berada di bawah rumpun linguistik. Sementara di Jerman, dengan kata philologie lebih mengacu pada kajian mengenai teks-teks sastra, khususnya teks-teks sastra Yunani-Romawi kuno dan kajian kebudayaan dan peradaban melalui dokumen-dokumen sastra.

Menurut Baroroh dkk. (1994: 3-5) filologi diartikan sebagai kebudayaan. Hal itu tercermin dari pendefinisiannya secara terminologis terhadap filologi yang diartikan sebagai ilmu yang mempelajari kebudayaan suatu bangsa berdasarkan bahasa dan kasusateraannya. Definisi yang diajukan Baroroh dkk. ini tampak sangat luas dan mirip dengan tujuan filologi itu sendiri. Yang bisa jadi pengertian itu dilihat dari sudut padangan sastra. Bila ditelisik lebih dalam konsep filologi yang ditawarkan Baroroh dkk. sangat mirip dengan hemeneutika filologis Schleiermacher (1834) dengan perluasan makna. Menurutnya tujuan penelitian filologi adalah memahami roh (geist) budaya Romawi-Yunani Kuno. Dalam titik inilah bisa jadi filologi disamakan dengan hermeneutika dengan pengertiannya yang awal (Poespoprodjo, 2004: 17-22).

Menurut Kridalaksana (1982: 60) filologi diartikan sebagai ilmu yang mempelajari bahasa, kebudayaan, pranata dan sejarah suatu bangsa seba- 
gaimana terdapat dalam bahan-bahan tertulis. Definisi ini lebih luas dari sebelumnya. Kajian filologi tidak hanya kebudayaan melainkan bahasa pun yang sebenarnya dalam praktek sebagai alat membedah tulisan kuno justru dipelajari. Selain itu, filologi juga mencurahkan kajiaannya terhadap sejarah bangsa pemilik naskah kuno tersebut. Pengertian dari Kridalaksana ini sejalan dengan kajian linguistik Arab modern yang mendefiniskan filologi-diterjemahkan filūlujiyyā-sebagai ilmu yang tidak hanya mengkaji bahasa dalam naskah-naskah kuno, melainkan mencakup kebudayaan, sejarah, tradisi dan sastra ('Abd Șabūr Syāhīn, 1984: 7).

Pengertian sangat spesifik mengenai filologi diungkapkan oleh Edwar Djamaris (2002: 3). Menurutnya filologi adalah ilmu yang meneliti naskah-naskah lama. Naskah, tambahnya adalah semua bahan tulisan tangan nenek moyang yang terdapat pada kertas, lontar, kulit kayu dan rotan. Asumsi ini didasarkan pada tulisan tangan yang tersimpan dalam media-media tersebut rentan dengan kerusakan. Apalagi jika berusia ratusan tahun, tentu banyak tanda baca yang hilang seperti titik dan huruf. Dengan begitu dibutuhkanlah suatu cara untuk merekontruksi tulisan tersebut. Pemfokusan pada naskah yang diutarakan Edwar (2002) ini selaras dengan penyataan filolog angkatan pertama dari Alexandria, Erastothenes (3 SM) (L. D. Reynold and N.G. Wilson, 1968: 1). Hanya saja pemfokusannya dikhususkan pada teks. Menurutnya, filologi merupakan ilmu yang mengkaji teks (kandungan) dari sebuah naskah. Maksud teks ini berbeda dengan maksud Baroroh dkk. Bagi Erastothenes teks adalah mengetahui maksud pengarang dengan jalan menyisihkan kesalahan-kesalahan dalam naskah. Seperti diketahui pada masa itu teks berada dalam beberapa naskah yang masing-masing mempunyai bacaan yang berbeda, bahkan ada pula yang sudah korup (rusak). Jadi, objek kajian filologi menurut Erastothenes adalah teks, namun begitu untuk mengetahui kandungan teks itu diharuskan meneliti telebih dahulu naskahnaskah yang mewadahinya.

Dalam tradisi Arab, pengertian filologi juga mengacu pada pengertian yang ditawarkan Erastothenes. Filologi seperti ini dikenal dengan istilah tạ̣qīq alnusu us yang berarti mengetahui hakikat sebuah tulisan atau teks. Sebagian filolog Arab seperti Șalāh al-Dīn al-Munajjad (1982: 65) menyebutnya, tạ̣qīq al-makhțțat. Orang yang melakukan kajian teks disebut muhaqqiq. Pentahqi $q$-an dalam keilmuan Arab setidaknya menyangkut empat hal; Pertama, apakah benar sebuah karya sastra (yang sedang diteliti atau dikaji) merupakan karya Asli pengarang sebagaimana yang disebut dalam judul naskah; Kedua, apakah isinya sesuai dengan mazhab pengarang; Ketiga, men-tahqi $\bar{i} q$ semua ayat-ayat al-Quran dan hadis dengan menyebut sumbernya dalam aparat kritik 
jika dalam teks yang dikaji tidak disebutkan; Keempat, memberikan penjelasan hal-hal yang diangap kurang jelas dalam teks (Musthafa, 2006: 2). Definisi ini menjelaskan secara teknis mengenai apa yang dilakukan dalam kajian filologi. Bila ditelisik pengertian tạqiiq ini juga belum bisa mewakili pengertian filologi dalam tradisi sebenarnya, bahkan bisa jadi tạqqīq merupakan bagiannya, sehingga dari sudut padang bahasa-baca: istilah-pun filologi dalam tradisi Arab belum mempunyai padanan kata. Biasanya diterjemah menggunakan sistem tadkhīl, yaitu filūlüjiyyā. Ada juga yang menyebutnya dengan istilah fiqh allughah. Hanya saja yang terahir ini banyak yang menentangnya (Emīl Badi ‘ Ya'qūb, 1982: 28-34).

Sementara Islam Nusanatara adalah sebuah ajaran yang Islam yang sudah menyatu dengan budaya Nusantara. Menurut Ketua Umum PBNU K.H. Said Aqil Siradj (2015-2020) Islam Nusantara adalah gabungan nilai Islam teologis dengan nilai-nilai tradisi lokal, budaya, dan adat-istiadat di Tanah Air. Menurut Said, Islam di Indonesia tidak harus seperti Islam di Arab atau Timur Tengah. Islam Nusantara, tegasnya, adalah Islam yang khas ala Indonesia. (republika.co.id, 10/03/2015). Sementara Kedua: Islam Nusantara dianggap sebagai perwujudan Islam yang bersifat empirik. Guru Besar Filologi Islam UIN Jakarta, Oman Fathurrahman, menyatakan bahwa Islam Nusantara itu adalah Islam yang empirik dan distingtif sebagai hasil interaksi, kontekstualisasi, indigenisasi, penerjemahan dan vernakularisasi Islam universal dengan realitas sosial, budaya, dan sastra di Indonesia (nu.or.id, 22/04/2015).

Secara akademik pemaknaan Islam Nusantara ini tergambar dari beberapa konsep yang sudah dicetuskan para pengkaji Islam Indonesia seperti Islam sinkretik (Geertz, 1981; Beatty 1999; Mulder, 2001), Islam akulturatif (Woodward, 1988), Islam sintesis (Ricklefs, 2012), Islam kolaboratif (Nur Syam, 2005), dan pribumisasi Islam (Gus Dur, 1998) dan Islam inklusif(Caknun, 1991). Konsep-konsep ini memiliki kesamaan dalam konteks bahwa Islamisasi baik dalam bentuk penanaman nilai, perilaku maupun pemikiran keagamaan di Nusantara berlangsung damai, harmonis dengan budaya, tradisi, nilai, dan adat istiadat lokal.

Dalam hal ini, tulisan ini tidak mau terjebak dengan perbedaan apakah Islam yang mempengaruhi atau budaya lokal yang mempengaruhi atau gabungan dari keduanya. Justru dengan kajian filologi terhadap manuskrip Islam Nusantara itu akan ditemukan Islam Nusantara yang sesungguhnya atau Islam yang "berdialek-tika" dengan budaya lokal.

Berdasarkan konsep di atas, pengertian filologi Islam Nusantara setidaknya dibagi menjadi dua; Pertama, filologi Islam Nusantara adalah filologi yang 
membahas tentang naskah kuno yang ditulis para ulama Nusantara atau pernah tinggal di Nusantara pada masa lampu; Kedua, filologi islam Nusantara diartikan sebagai Filologi yang mengkaji teks-teks kuno yang ditulis ulama Nusantara atau pernah tinggal di Nusantara pada masa lampau. Kedua definisi ini bisa jadi terpisah atau hanya bergerak pada naskah saja, bisa pula digabung. Jika digabung, secara praktik maka kedua definisi itu berurutan, dimulai dari mengkaji manuskrip Islam Nusantara kemudian dilanjutkan mengkaji teks dari naskah tersebut. Pengertian hanya mengkaji naskah Islam Nusantara bukan berarti menafikan teksnya, melainkan teks tidak dikaji secara mendalam, karena yang menjadi fokusnya adalah bagaimana naskah—baca tulisan—bisa terbaca masyarakat Indonesia sekarang Sementara kebudayaan, sastra, ilmu pengetahuan sebagaimana diungkapkan beberapa tokoh di atas terkat pendefinisian filologi adalah contoh-contoh pengetahuan yang terdapat dalam naskah Islam Nusantara.

Setelah memperhatikan penjelasan definisi di atas, objek kajian filologi Islam nusantara dibagi menjadi dua, yakni naskah dan teks yang ditulis ulama Nusantara. Pertama, naskah atau yang biasa disebut manuskrip dan sering disingkat 'MS' untuk naskah tunggal dan 'MSS' untuk naskah jamak-baca: banyak - merupakan sumber primer dalam kajian filologi Islam Nusantara. Kata naskah berasal dari bahasa Arab, nuskhah yang berarti lembaran, tulisan tangan dan tempat menulis. Dalam bahasa Inggris kata ini disepadankan dengan frasa written by hand (menulis dengan tangan) atau yang lebih dikenal dengan sebutan manuscript. Kata manuscript manuscript diambil kata "manu" dan "scriptus". Handscript adalah penyebutan di dalam bahasa Belanda, yang berarti tangan dan tulisan. Sementara dalam bahasa Latin disebut "codex". Menurut Tjandrasasmita (2006: 3-5) naskah adalah dokumen yang ditulis tangan secara manual di atas sebuah media seperti kertas, papirus, daun lontar, daluwang dan kulit binatang. Jadi naskah Islam Nusantara adalah hasil karya ulama Nusantara atau yang tinggal di Nusantara yang tekait dengan tema-tema keislaman yang ditulis dengan tangan pada masa mulai abad ke-13 sampai sekarang ini.

Kedua, teks adalah sesuatu abstrak yang hanya bisa dibayangkan saja dan merupakan kandungan atau isi naskah Islam Nusantara. Sebuah naskah bisa jadi mengandung satu atau lebih teks, bahkan terkadang berisi topik atau tema dalam bidang keilmuan yang berbeda-beda. Ini dikarenakan keterbatasan bahan tulis pada masa lalu, sementara penulis ingin mengabadikan pemikirannya dalam bentuk tulisan. Perbedaan antara keduanya semakin jelas ketika terdapat naskah muda tetapi mengandung teks tua. Artinya, dalam naskah muda 
terkandung ide-ide atau cerita zaman dahulu dari para ulama klasik yang sudah tua usianya.

Dalam tradisi intelektual Islam-Indonesia, pengertian teks dibedakan lagi menjadi matan (matn), komentar (syarḥ) dan penjelasan (ḥ̂̄syiyah). Matan adalah teks utama yang menjadi landasan bagi setiap pengarang. Sedangkan syraḥ dan hăsyiyah ditulis untuk memmbantu memahami matan, yang umumnya, ditulis bukan pengarang matan itu. Karya klasik Nusantara yang memuat matn, syarḥ dan hāsyiyah ini tergolong sangat banyak, sehingga kajian filologis naskah keislaman Nusantara klasik tidak hanya dibatasi pada pengertian teks saja, melainkan diperkaya dengan ketiga istilah lainnya.

Teks sebagai objek kajian filologi Islam Nusantara diasumsikan mengalami perubahan dalam transmisinya hingga perlu dikembalikan seperti aslinya. Perubahan-perubahan teks terjadi dikarenakan ada penyalinan yang tidak setia sehingga menghasilkan teks yang korup, yang pada gilirannya terjadi variasivariasi teks (Nafron Hasjim, 1985: 161). Dalam prinsip filologi, variasi teks ini dianggap sebagai kesalahan yang harus dibersihkan. Variasi teks ini dapat diklasifikasi menjadi fisik dan psikologis (Gilbert J. Garraham, 1957: 226). Kesalahan pertama diakibatkan oleh ulama atau para pewarisnya seperti perawatan, bahan naskah, tinta dan cuaca. Sedangkan kesalahan kedua diakibatkan oleh kesalahan para ulama klasik sendiri yang berupa kesalahan pemahaman, pembacaan dan subjektivitas penyalin baik disengaja maupun tidak. Di antara variasi teks yang diakibatkan kesengajaan ulama sendiri adalah pergantian huruf yang mirip karena penulisan kurang jelas, pertukaran letak suku kata (transposisi), pergantian kata yang maknanya sama (sunbstitusi), perubahan ejaan dan penularan kata (kontaminasi). Variasi teks dalam penyalinan yang tidak disengaja manusia di antaranya: beberapa bagian teks terlampaui (lakuna) yang mencakup huruf ke huruf yang sama (haplografi); kata ke kata yang sama (saut du meme au meme), satu baris, larik atau bahkan bait (litografi) dan adannya hal yang berlebih dalam teks (dittografi) yang mencakup ulang tulis huruf; ulang tulis suku kata dan ulang tulis kata yang sama (Musthafa, 2006: $3-4)$.

\section{Metodologi Kajian Naskah Islam Nusanatara}

Secara metodologis filologi merupakan ilmu tạtbiq atau aplikatif. Artinya ilmu yang langsung siap digunakan untuk menganalisis objeknya. Teori-teori filologi dalam penelitian filologi juga merupakan metode yang digunakan. Hal ini berbeda dengan ilmu-ilmu teoritis yang masih membutuhkan metode sebagai operasional dari teori-teori di dalamnya. Dengan kata lain, dalam kajian filologi 
perlu dibedakan antara metode filologi dan metode penelitian filologi. Yang pertama-biasanya disamakan dengan istilah 'kritik teks'-mengandaikan bahwa metode tersebut berada dalam ranah teoritis yang bisa jadi masih abstrak dengan menggunakan istilah-istilah teknis dalam ilmu ini. Sementara pengertian yang kedua mengasumsikan bahwa metode ini bersifat operasional layaknya di metode-metode penelitian ilmiah lain. Selain tent unya, dalam metode penelitian filologi mempunyai istilah-istilah teknis sendiri.

Metode filologi secara garis besar sebagaimana diungkapkan Darusuprapta (1985: 22) dibagi menjadi dua, yang tergantung dari naskah yang ditemukanbaca dikaji. Apakah naskah berbentuk jamak ataukah tunggal. Jika jamak maka metode yang digunakan adalah metode gabungan, stema, dan landasan. Jika tunggal metode yang digunakan adalah facsimile, diplomatik dan kritis. Pembagian yang didasarkan pada jumlah naskah juga dilakukan oleh Baroroh. Hanya saja, untuk naskah jamak ia menambahkan metode int uitif, sementara metode stema diganti dengan istilah metode objektif. Selain itu, Untuk naskah tunggal Baroroh hanya membagi menjadi dua, yaitu metode diplomatik dan standar (Siti Baroroh Baried dkk., 1985: 4). Pengertian kedua metode ini juga berbeda dengan sebelumnya. Diplomatik diartikan sebagai facsimile dan standar adalah diplomatik seperti yang dimaksud Darusuprapta. Pembagian Baroroh ini juga diikuti dosen Filologi UIN Kalijaga Yogyakarta (Musthafa, 2006: 25-27).

Adalah Oman Fathurrahman (2010: 21-25), filolog Nusantara Melayu, membagi metode kritik teks tidak didasarkan pada jumlah naskah melainkan pada cara analisisnya. Oman membagi metode kritik teks-yang dibahasakan dengan metode penelitian filologi-menjadi empat sebagaimana metode dalam naskah tunggal yang diutarakan Darusuprapta, kemudian ditambah dengan edisi campuran (gabungan, elektik). Yang perlu digaris bawahi di sini, Oman tidak menyebut metode-metode tadi dengan istilah "metode", melainkan "edisi".

Selain mempunyai metode secara teoritik seperti di atas, sebagai displin ilmu tent unya filologi memiliki metode penelitian khusus yang berbeda dengan displin ilmu lain untuk menangani objek kajiannya. Secara substansial metodemetode dalam penelitian filologi relatif sama dan antar-tokoh tidak banyak perdebatan. Hal ini dikarenakan "matang" dan "tua"nya ilmu ini, sehingga dalam historisitas, cara yang digunakan untuk meneliti naskah dan teks sudah "pakem". Secara teknik, langkah-langkah dalam penelitian filologi adalah inventarisasi naskah, deskripsi naskah, perbandingan teks naskah, kritik teks, 
struktur edisi teks (penyajian data) dan pertanggungjawaban edisi teks (Oman Fathurrahman, 2010: 21-25, Siti Baroroh Baried dkk., 1985: 21-25)

Berdasarkan konsep dan metodologi di atas, kajian filologi juga bisa diterapkan terhadap manuskrip Islam Nusantara. Ini dikarenakan metode yang ditawarkan filologi tidak dibatasi pada naskah tertentu, melainkan seluruh naskah kuno bisa dikaji. Hanya saja butuh penyesuaian bahasa dan isi (teks). Sebagaimana diketahui, naskah Islam Nusantara rata-rata menggunakan bahasa Arab atau Arab Pegon (Jawa atau Melayu). Sementara teks (isi) manuskrip Islam Nusantara adalah ajaran-ajaran keislaman yang didominasi bidang fikih, tasawuf dan tauhid yang menyebar di berbagai belahan Indonesia, terutama dalam masyarakat pesantren.

Artinya, dengan karakteritik itu maka filolog manuskrip Islam Nusantara minimal harus memiliki kompetensi bahasa Arab atau bahasa lokal yang digunakan di Indonesia dan materi-materi keislaman secara umum. Kompetensi dimaksudkan untuk mempermudah dalam mengkaji teks-teks Nusantara.

\section{Signifikansi Manuskrip Islam Nusantara}

Dengan meminjam konsep Haryati Soebadio (1975) seperti dikutip Edwar Djamaris (2002: 7) signifikansi kajian filologi Islam Nusantara adalah mendapatkan kembali naskah yang bersih dari kesalahan, sehingga diketahui manuskrip yang paling dekat dengan aslinya. Dengan kata lain, setidaknya dengan adanya kajian filologi, manuskrip Islam Nusantara yang sudah disalin oleh berbagai generasi direkonstruksi kembali menjadi naskah yang kebenarannya mendekati aslinya. Bahkan lebih spesifik filologi digunakan sebagai kritik teksteks Islam unt uk menemukan teks Islam Nusantara yang asli (autografi) dan yang mendekati kebenaran (autoritatif). Dengan demikian filologi sebagai pendekatan dalam mengkaji naskah-naskah Islam Nusantara tidak hanya menyusun teks outoritatif, melainkan-sebisa mungkin-melacak dan menemukan teks autografi. Setelah itu, men-transliterasikan teks tersebut dengan menjaga keaslian atau ciri khusus penulisan kata dan menerjemahkannya ke dalam bahasa yang mudah dipahami masyarakat sekarang atau bahasa Indoensia, menyunting teks dengan kaidah bahasa sekarang dan mendeskripsikan kedudukan dan fungsi naskah-teks yang diteliti supaya dapat diketahui tempat dan manfaatnya.

Argumentasi di atas merupakan tujuan khusus pendekatan filologi dalam mengkaji teks Islam Nusantara, yakni menyunting sebuah teks keislaman yang dipandang paling dekat dengan teks asli dan mengungkap sejarah terjadi teks dan perkembangannya, serta mengungkap resepsi para masyarakat Nusantara pada setiap kurun penerimaannya. Sementara secara umum signifikansi filologi 
dalam mengkaji teks Islam Nusantara adalah memahami sejauh mungkin kebudayaan Islam Nusantara lewat hasil sastranya baik lisan maupun tulis, memahami makna dan fungsi teks Islam bagi masyarakat penciptanya, mengungkapkan nilai-nilai budaya lama sebagai alternatif, pengembangan kebudayaan Islam dan melestarikan warisan budaya Nusantara (siti Baroro Baried: 1994: 5-6).

Selain itu secara keilmuan praktis kajian terhadap manuskrip Nusantara memiliki beberapa manfaat; Pertama, menggali dinamika Islam dan masyarakat Muslim Indonesia dan sekitarnya. Ini dikarenakan manuskrip Islam Nusantara selain menggunakan bahasa Arab ditulis menggunakan bahasa lokal seperti Melayu, Aceh, Bali, Batak, Belanda, Bugis-Makassar-Mandar, Jawa dan Jawa Kuna, Madura, Melayu, Minangkabau, Sanskerta, Sasak, Sunda dan Sunda Kuno, Ternate, Wolio, bahasa-bahasa Indonesia Timur, bahasa-bahasa Kalimantan, dan bahasa-bahasa Sumatra Selatan, sehingga mengkajinya berarti akan menjadi semacam 'jalan pintas' untuk mengetahui pola-pola hasil interaksi dan pertemuan Islam dengan budaya-budaya lokal di Nusantara, yang tent unya menjadi kekayaan intelektual tersendiri; Kedua, kajian atas naskahnaskah Islam Nusantara dengan sendirinya akan menjadi bagian dari upaya pelestarian (preservation) benda cagar budaya Indonesia demi menjaga identitas kemajemukan, kebangsaan, dan menjamin keberlangsungan transmisi pengetahuan yang telah diwariskan sejak rat usan tahun lalu; Ketiga, memetakan kejayaan tradisi intelektual Islam Nusantara dapat menunjukkan kepada dunia internasional bahwa Nusantara bukan wilayah pinggiran (peripheral part), melainkan bagian tak terpisahkan (integral part), dari dunia Islam secara global (Oman Fatkhurrahman, 2011).

\section{E. Kontekstualisasi Filologi dalam Mengkaji Teks Nu- SANTARA}

Pada kajian filologi klasik atau konvensional menjadikan edisi teks yang siap dibaca masyarakat sekarang merupakan tahapan akhir. Namun demikian seiring perkembangan dan perbandingan dengan displin ilmu lain, filologi klasik dianggap "kering”. Ini dikarenakan filologi diasumsikan hanya berkutat pada "pembenahan kesalahan tulisan" saja sehingga mirip editor. Selain itu, filolog hanya menyediakan bahan mentah untuk dikaji displin ilmu lain. Padahal yang lebih "tahu" ke dalam dan lika-liku teks yang disunting adalah filolog itu sendiri. Sehingga yang lebih berhak mengkaji edisi teks itu adalah penyunting it u sendiri. Ibarat masakan, filolog menyediakan masakan, tetapi tidak menikmati masakan itu, dikarenakan dimakan ilmuwan lain. Atas dasar inilah, 
kajian filologi dikembangkan dengan usaha kritis, analitis dan kontekstual berkaitan dengan tema dan wacana yang terkandung dalam teks dengan tujuan memahami keutuhan sejarah teks tersebut dalam sebuah konteks yang melahirkan (Oman Faturahman dkk., 2010: 42).

Perkembangan kajian filologi di atas biasa disebut dengan istilah dirāsah taḥqiq al-nusūu (kontekstulasiasi filologis). Kajian filologi tidak lagi diletakkan sebagai ilmu yang berdiri sendiri, melainkan - meminjam istilah Amin Abdullah (2013)_-"dikoneksikan" dengan ilmu-ilmu lain. Atau dalam tipologi keilmuan postmodern seperti dijelaskan dalam filsafat ilmu disebut filologi "dimultidisplinerkan” dengan ilmu-ilmu lain. Artinya, secara metodologis kajian teks masih "pakem" menggunakan metode yang terdapat dalam ilmu filologi, namun hasil filologis dari edisi teks dikaji dan diperkaya dengan pendekatanpendekatan lain. Pendekatan yang digunakan untuk menganalisis teks ini sangat bervariasi, tergantung dari tema dan wacana yang terdapat dalam teks itu.

Secara umum — sepanjang pengamatan penulis — kontekstualisasi filologis ini dipetakan menjadi dua, yakni subjektif dan objektif. Kedua istilah ini, penulis pinjam dari konsep hermeneutika objektif (rekonstruktif) Wilhelm Dilthey (183311911) dan hermeneutika subjektif (konstruktif) H.G. Gadammer (1889-1976) (Kaelan, 2010: 268-272 dan 283-294). Kontekstualisasi objektif adalah usaha kritis, analitis dan kontekstual yang memposisikan teks pada masa itu sehingga perlu dikaji hubungan gramatika, jaringan teks yang lain (intertektualitas), pengarang dan konteks sosiologis saat teks dilahirkan. Kehadiran teks dipadang tidak berangkat dari ruang kosong. Dalam menemukan makna teks objektif, penyunting harus memproduksi atau merekonstruksi makna sebagaimana dimaksud penulis naskah. Seakan-akan penyunting mangalami peristiwa historis seperti yang dialami pengarang naskah. Dalam bahasa Dilthey disebut dengan historical understanding (kemampuan sejarah). Dengan begitu, edisi teks juga bisa dibahas dan dikaji dari sudut padangan sejarah di mana teks itu lahir, diproduksi dan dimaknai oleh pengarang. Ini misalnya karya Oman Fathurrahman (2003), Tarekat Syatariyah di Minangkabau, karya Hermansyah (2012), Tibyān fï Ma'rifah al-Adyān: Tipologi Sesat Menurut Nūr al-Dīn ar-Ranairī dan Azyumardi Azra (2007) dengan karyanya. Jaring-Jaring Ulama Timur Tengah dan Kepulauan Nusantara Abad XVII \& XVII. Yang terakhir, merupakan inisiator kajian filologis kontekstual objektif. Dalam karya Azra, sekitar 27 manuskrip Nusantara seperti karya al-Palembanì, al-Makassarì, as-Sinkilì dan lain-lain dijadikan sebagai basis utama. 
Adapun filologis kontekstual subjektif adalah usaha kritis, analitis dan kontekstual yang memposisikan teks pada masa sekarang yang terput us dari pengarang dan masa kelahiran teks. Pemaknaan dan penafsiran terhadap teks diserahkan pada pembaca-baca penyunting. Memahami pemikiran penulis naskah dengan menelusuri latar belakang sejarah, budaya dan tujuan pengarang secara ut uh oleh filologi subjektif ini dianggap sangat sulit, bahkan bisa dikatakan tidak mungkin. Dengan kata lain, pemaknaan terhadap edisi teks itu dilakukan dengan cara teknik dan metode yang diarahkan kepada dan berasal dari teks naskah itu sendiri. Umumnya teks langsung dianalisis menggunakan teori-teori modern. Contoh filologi subjektif ini adalah karya Karsono H. Saputra (2010), Cerita Panji: Reperesentasi Prilaku Jawa, Penelitian Endang Poerwanti (2011), "Meretas Nilai-Nilai Moral dan Pendidikan Karakter dalam Naskah Wulangreh dan Wedhatama", penelitian Khabibi Muhammad Luthfi (2013), "Cerita Nabi Muhammad Berhempas dengan Abu Jahil Karya Buya Abdus Salam: Menyemai Pendidikan Karakter Berbasis Nilai-Nilai Islam” dan lain-lain.

Dalam percaturan filolog Indonesia generasi baru ini dimotori oleh Oman Fatkhurrahman, Guru Besar UIN Syarif Hidayatullah Jakarta. Meskipun Oman merupakan "murid" dari generasi tua seperti Ikram Achadiati (2013) Guru besar Filologi Universitas Indonesia dan Hamamah Sutrisno (2013) Guru Besar Filologi Universitas Gadjah Mada, Oman mendobrak tradisi pendahulunya. Bahkan secara khusus Oman memberikan istilah tambah dengan menyebut filologi plus. Tidak itu saja, beberapa dosen muda yang mengajar filologi dari UIN Sunan Kalijaga Yogyakarta dan Universitas Gadjah Mada misalnya Musthofa, Fadlil Munawar Kholil, dan lain-lain juga mengikuti mazhab baru filologi ini. Tren Filologi baru ini juga merambah ke berbagai penelitian ilmiah doktoral dan pascasarjana yang ada di kampus-kampus tersebut. Para mahasiswa tidak hanya terhenti pada tahqiq al-makhtutāt saja, tetapi berusaha mendirāsah-nya. Dan, bisa jadi tradisi baru kontekstualisasi ini juga berjalan di berbagai universitas dalam negeri lain, bahkan luar negeri.

Namun demikian, progresifitas filologi-baru ini juga menuai kritik, terutama dari tokoh-tokoh senior. Bagi tokoh senior, Dirāsah filūiūjiyyah dianggap tidak lagi mencerminkan akar historis keilmuannya. Kajian naskah klasik dicampur-adukkan dengan berbagai varian keilmuan, sehingga sulit membedakan antara filologi dan disiplin lain. Selain tent unya, ontologis dan epistemologi filologi yang dibangun mulai abad Romawi akan bergeser. Dan yang pasti, untuk menjadi filolog semakin berat. Karena harus menguasai berbagai disiplin ilmu. 


\section{Ibdg' Jurnal Kebudayaan Islam}

Menyikapi kedua kutub mazhab di atas tampaknya filologi baru lebih relevan dalam dalam kajian naskah Islam klasik dan tent unya harus didahului kajian filologi klasik. Namun demikian kajian filologi Islam Nusantara juga tidak menut up kemungkinan memiloh salah satu dari mazhab itu. Ini berangkat dari kompleksitas disiplin ilmu yang yang dimiliki oleh para sarjana muslim Indonesia. Hal ini juga diamini Oman Fatkhurrahman, bahwa para sarjana Muslim Indonesia memiliki kemampuan untuk melakukan kajian filologis ini, baik yang murni maupun plus. Di antara alasannya yaitu pertama, para sarjana Muslim Nusantara merupakan sumber daya manusia (human resources) yang memiliki potensi besar dalam menginte-grasikan kajian bidang-bidang keislaman dengan bidang umum termasuk Budaya dan Humaniora. Potensi ini ditunjang dari sebagian para Intelektual muslim Indonesia berasal dari komunitas yang memiliki akar keilmuan Islam di pesantren-pesantren dan madrasah, sehingga sangat menguasai topiktopik yang dibahas dalam literatur Islam klasik, termasuk dalam manuskripmanuskrip Islam Nusantara. Kedua, mayoritas sarjana Muslim Nusantara memiliki kemampuan bahasa yang banyak digunakan dalam manuskrip, yakni bahasa Arab. Apalagi berbagai manuskrip dalam bahasa daerah pun umumnya ditulis dengan aksara Arab (Jawi dan Pegon), sehingga penguasaan atas aksara dan bahasa tersebut menjadi sangat penting. Sejauh ini, minimnya penguasaan para filolog yang umumnya berlatar belakang pendidikan umum - terhadap bahasa Arab seringkali menjadi faktor penghambat dilakukannya penelitian atas manuskripmanuskrip Islam tersebut, sehingga tidak mengherankan jika puluhan ribu manuskrip Nusantara berbahasa Arab lebih banyak "ditelantarkan" (Oman Fatkhurrahman, 2011).

\section{F. Simpulan}

Filologi termasuk salah satu ilmu yang bisa digunakan untuk mengkaji manuskrip Islam Nusantara dengan tujuan untuk menghasilkan teks otentik atau otoritatif yang siap dibaca masyarakat Indonesia sekarang. Metode filologis yang digunakan unatuk mengkajinya setidaknya ada tujuh, yaitu metode faksimili, diplomatik, kritis, landasan, stema, gabungan dan intuitif. Agar metode filologi ini bersifat aplikatif-teknis maka dibutuhakn metode penelitian filologi. Secara sitematis metode penelitian filologi adalah inventarisir naskah, deskripsi naskah, perbandingan teks naskah, kritik teks, edisi teks dan pertanggungjawaban edisi. Filologi tidak hanya menyajikan edisi teks saja, melainkan membahas dan menganalisis edisi teks tersebut dengan pendekatan-pendekatan ilmu lain. Pendekatan yang digunakan dalam menganlisa edisi teks Islam Nusantara itu menyesuaiakan topik dan dan tema yang dikandungnya. Ini 
dibuktikan dengan naskah-naskah Nusantara yang belum "tersentuh" dan tersimpan rapi di pribadi atau kolektor masih berserakan. Salah satu buktinya adalah adanya sakralitas terhadap teks-teks kuno tesebut, sehingga teks hanya tidak boleh "diapa-apakan" manusia. Ini berbeda jauh dengan tradisi filologis di Eropa, yang konon sudah mancapai final, karena semua naskah-naskah kuno sudah di-tahqiq . Atas dasar ini sudah menjadi tugas bersama, khususnya caloncalon filolog baru unt uk segera mengeksplorasi manuskrip Islam Nusantara, agar generasi sekarang dapat "membaca" dan mengambil manfaat ilmu yang terkandung di dalamnya. Sehingga ada ketersambungan pengetahuan antara generasi Islam lampau dan sekarang. Bahkan bila perlu, menggunakan pendekatan filologi baru, sehingga paham mengenai apa itu Islam Nusantara.

\section{Daftar Pustaka}

Azra, Azyumardi. 2012. "Manuskrip dan Rekonstruksi Sejarah Intelektual Muslim Nusantara" pelatihan Short Course Metodologi Penelitian Filologi tahun 2012 yang diselenggarakan Manassa bekerjasama dengan Diktis Ditjen Pendidikan Islam Kementerian Republik Indonesia pada tanggal 26 Juli 2012.

Azra, Azyumardi. 2007. Jaring-Jaring Ulama Timur Tengah dan Kepulauan Nusantara Abad XVII \& XVII. Cet. III. Prenada Media Group.

Baried, Siti Baroroh dkk. 1994. Pengantar Teori Filologi. Yogyakarta: BPPF Fakultas Sastra Universitas Gadjah Mada.

Baried, Siti Baroroh dkk. 1994. Pengantar Teori Filologi. Yogyakarta: BPPF Fakultas Sastra Universitas Gadjah Mada.

Darusuprapta. 1985. "Ikhtisar Metode Kritik Teks" Makalah dalam Penataran

Metodologi Penelitian Filologi Tahap Pertama yang diselenggarakan oleh Lembaga Research dan Survey IAIN—sekarang menjadi UIN-Sunan Kalijaga Yogyakarta.

Djamaris, Edwar. 2002. Metode Penelitian Filologi. Jakarta: CV Manasko. Endang Poerwanti. 2011. Meretas Nilai-Nilai Moral dan Pendidikan Karakter dalam Naskah Wulangreh dan Wedhatama. Makalah Mangubagja dalam Kongres Bahasa Jawa ke-V.

Fathurahman, Oman. dkk. 2010. Filologi dan Islam Indonesia. Jakarta: Puslitbang Lektur Keagamaan.

Fatkhurrahman, Oman. "Memahami Islam Nusantara Melalui Kitab: Sebuah Refleksi”. http://oman.uinjkt.ac.id/2011/08/memahami-islam-nusantaramelalui.html. Diakases pada 11 November pukul 21.13 WIB. 
Fatkhurrahman, Oman. 2003. Tarekat Syatariyah di Minangkabau. Jakarta: Piramedia Group.

Garraham, Gilbert J. 1957. A Guide to Historical Method. New York: Fordham University Press.

Hasjim, Nafron. 1985. Pengantar Teori Filologi. Jakarta: Pusat Pembinaan dan Pengembangan Bahasa Departemen Pendidikan dan Kebudayaan.

Hermansyah. 2012. Tibyān fĩ Ma'rifah al-Adyān: Tipologi Sesat Menurut Nūr ad-Din ar-Ranirī. Banten: Lembaga Studi Islam Progresif.

Kaelan. 2010. Filsafat Bahasa, Semiotika dan Hermeneutika. Yogyakarta: Paradigma.

Kridalaksana. 2008. Kamus Linguistik. Jakarta: Gramedia Utama.

Luthfi, Khabibi Muhammad. 2012. Cerita Nabi Muhammad Berhempas dengan Abu Jahil Karya Buya Abdus Salam: Menyemai Pendidikan Karakter Berbasis Nilai-Nilai Islam. Jakarta: Direktorat Pendidikan Tinggi Islam dan Masyarakat Naskah Nusantara Manassa.

Munajjad, Șalāh al-Dīn al-. 1982. Qawā'id al-Mahtụtạt. Bayrūt: Dār al-Kitāb al-Jadid.

Musthafa. 2006. Filologi. Handout Mata Kuliah Filologi Jurusan Bahasa dan Sastra Arab Fakultas Adab UIN Sunan Kalijaga Yogyakarta.

nu.or.id, 22/04/2015.

Poespoprodjo. 2004. Hermeneutika. Bandung: Pustaka Setia.

republika.co.id, 10/03/2015.

Robinson, T. H. 1992. Linguistik Umum; Suatu Pengantar. Terj. Soenarjati. Yogyakarta: Kanisius.

Saputra, Karsono H. 2010. Cerita Panji: Reperesentasi Prilaku Jawa. Jurnal Jumantara. Vol. I. No. 1.

Syāhīn, 'Abd Șabūr. 1984. Fì 'Ilm al-Lugah al-'Ām. Bayrut: Muassisah alRisālah.

Tjandrasasmita, Uka. 2006. Naskah Klasik dan Penerapannya bagi Kajian Sejarah Islam di Indonesia. Jakarta: Puslitbang Lektur dan Kazanah Keagamaan Badan Litbang dan Diklat Kemenag RI.

Wilson, L. D. Reynold dan N.G. 1968. Scribes and Scholars. London: Oxford University Press.

Ya'qūb, Emīl Badi'‘ 1982. Fiqh al-Lugah. Bayrut: Dār al-Saqāfah al-Islāmiyyah. Zaid, Nasr Hamid Abu. 2003. Tekstualitas al-Qur'an Kritik terhadap Ulumul Qur'an. Terj. Khoiron Nahdiyyin. Yogyakarta: LKiS. 